\title{
- ב......... \\ The Competition of Authoritative Languages and Aquinas's Theological Rhetoric
}

\author{
MARK D. JORDAN
}

One cliché in the iconography of Thomas Aquinas shows the saint, abstracted, counting off arguments on his fingers. ${ }^{1}$ The image is quite clearly of an effort of memory, but we moderns are liable to mistake what is being remembered. To us, the image seems to show Thomas recollecting principles and excogitating arguments. In fact, Thomas counts off on his fingers terms, topics, and classifications learned from texts that he has inherited. ${ }^{2}$ The inherited texts speak a multiplicity of languages. The constant activity of Thomas's

1. Examples can be found in George Kaftal, Iconography of the Saints in Tuscan Painting (Florence: Sansoni, [1952]), \#297, 1', figure 1109; Kaftal, Iconography of the Saints in Central and South Italian Schools of Painting (Florence: Sansoni, [1965]), $\# 385,1^{\prime}$, figure 1277 .

2. The modern equivalent would thus be Thomas surrounded by books of indexed sources. There are a few images of Thomas amid books in the late medieval iconography. See Kaftal, Iconography of the Saints in the Painting of North East Italy (Florence: Sansoni, 1978), \#294, 8, figure 1264. I would put the emphasis on indexed sources ready to hand, rather than on originals read and remembered whole. For evidence of Thomas's research habits, not to say of the speed at which he composed, see Jean-Pierre Torrell, Initiation à saint Thomas d'Aquin (Fribourg: Éds. Universitaires de Fribourg, and Paris: Éds. du Cerf, 1993), pp. 351-355. Compare the more credulous depiction of Thomas in Mary Carruthers, The Book of Memory: A Study of Memory in Medieval Culture (Cambridge: Cambridge University Press, 1992), pp. 2-6. 
theological writing is to affirm their multiplicity, and so it is not possible to understand him except by hearing how many languages there are. Modern readers are for the most part deaf to the play of these languages in Thomas, for two sorts of reasons. On the one hand, readers are simply ignorant that they encounter inherited languagesthey miss Thomas's gestures of quotation, allusion, appropriation, correction. On the other hand, they lack ways of understanding how Thomas would have received these languages. Modern readers tend to mistake the reception for eclecticism, for the operation of "sources and influences," or for a diffident masking of a "system" of Thomas's own devise.

I will propose here another way of conceiving Thomas's inheritance of theological languages. One immediate difficulty in making the proposal is the use of the term 'language' to describe the objects of Thomas's concern and the means of his composition. I will use 'language' to cover three features of theological discourse that are connected in Thomas, but not named by him with a single term. The first feature, the most evident in theological composition, is what Thomas calls the "manner of speaking." This modus loquendi comprises what we would call technical terminologies, but also argumentative procedures, typical metaphors or tropes, and tested rhetorical strategies. The second feature is the incorporation of a host of texts and pieces of texts that fix patterns and set limits for the deployment of technical terms-what are called, in the slang of the Schools, auctoritates. A Latin-speaking theologian of Thomas's time doesn't just receive the word 'substantia' and a set of procedures or metaphors or strategies for deploying it. He also receives hundreds of specific examples showing permitted and prohibited uses of 'substantia'. The third feature is the natural language (lingua) within which a theological modus loquendi is constructed. Different possibilities for theological expression are offered by the different national languages, say, by patristic Greek and medieval Latin. I will try to show the interconnection of these three features below, in the section on Thomas's teaching about multiple 'languages'.

My grouping these features together under the English 'languages' is a confession of having read Wittgenstein. The confession is lexical, not philosophical. I mean to assert no doctrinal similarities-or even the possibilities of similarity-between Wittgenstein and Aquinas. I do mean to suggest that Aquinas would have agreed with at least 
this remark from the Investigations: "Our language can be seen as an ancient city; a maze of little streets and squares, of old and new houses, and of houses with additions from various periods; and this surrounded by a multitude of new boroughs with straight regular streets and uniform houses."3 Better to begin in Thomas with this picture than with assumptions about eclecticism or absorbed "sources" or masked "systems." If Thomas would complicate Wittgenstein's optimistic chronology, if he would multiply the architectural styles needed for a habitable city, he would very much agree that theology is a knowledge learned in and applied to an ancient city of Christian discourses.

\section{ON RECOVERING THOMAS'S "SOURCES"}

The term 'source' is a sedimented metaphor of origin: it hints that the text using sources is secondary, derivative, belated. Originality and purity lie further back, further up stream. To speak of 'sources' is for this reason much like speaking of a "sincere" manuscript - Housman's instance of a badly misplaced "moral sympathy."4 But we rarely suffer scruples over our category because the effort to identify what seem to us Thomas's 'sources' seems so venerable. Readers have been inserting citations into Thomas's texts for seven centuries in the effort to learn them and to teach them. As one generation of readers succeeded another, more and other citations were needed. Indeed, two different sorts of citations must now be added to Thomas's texts as to other works of medieval academic theology. The first sort fills in an incomplete allusion or quotation. The second, by far the more important, marks off and identifies implicit references.

To take the easier first: Thomas assumes that his readers are roughly as familiar as he is with the disposition of received authorities around standard theological topics. He cuts his references to the minimum,

3. Ludwig Wittgenstein, Philosophical Investigations, trans. G. E. M. Anscombe (New York: Macmillan, 1970), p. 8, \#18.

4. A. E. Housman, "The Application of Thought to Textual Criticism," as in The Classical Papers of A. E. Housman, ed. J. Diggle and F. R. D. Goodyear, 3 (Cambridge: Cambridge University Press, 1972), pp. 1058-1069, at pp. 1063-1064. 
especially when dealing with a famous or reiterated text. Where Thomas does provide a brief citation, it may be according to a scheme of numeration-or even of titles-very different from the schemes familiar to his latter-day readers. Moreover, and after filling in the citation, there is the task of finding the text that Thomas cites. Few texts are lucky enough to have modern editions of their medieval versions. A modern reader can find John Damascene about as Thomas would have found him or can read, with some patience, Saracenus's rendering of Ps-Dionysius, the translation Thomas used as his main text. ${ }^{5}$ Still the reader is far from having anything like the Dominican library at Paris as it would have been in 1255 . She could not with any assurance reconstruct the catalogue of that library. ${ }^{6}$

To remark this ignorance is not pedantry. A reader cannot judge Thomas's literal commentaries on Aristotle, on Ps-Dionysius, or on Scripture unless she has his littera, that is, the text he comments. Thomas was esteemed by many of his early readers, even those not otherwise sympathetic, precisely for his exegetical attention to detail. A reader cannot appreciate his attentiveness, his teaching as an exegete, if she holds a different text. The failure of appreciation matters because the center of theological procedure in Thomas is disputative exegesis. Almost any article in the Summa, in the Scriptum on Peter Lombard's Sententiae, or in the disputed questions turns upon dialectically stressed interpretations of textual authorities. Unless a

5. John Damascene, De fide orthodoxa: Versions of Burgundio and Cerbanus, ed. Eligius M. Buytaert (St. Bonaventure, N.Y.: Franciscan Institute, 1955); Dionysiaca: Receuil donnant l'ensemble des traductions latines des ouvrages attribué au Denys l'Aréopage . . . e ed. Philippe Chevallier et al. (Paris and Bruges: Desclée, de Brouwer, 1937). By saying that we have Thomas's versions, I do not mean to say that we have them in the way that he did. The difference between reading a modern edition and a medieval manuscript is very great, and not all to the credit of the former. A manuscript forces one to read slowly, and many manuscripts intended for reference use encircle the main text with a marvelous array of exegetical aids.

6. Most inventories so far published for Dominican houses date from around 1400. No systematic study has been made of the earlier materials. For samples of the later inventories, see Thomas Kaeppeli, "Antiche biblioteche domenicane in Italia," Archivum Fratrum Praedicatorum 36 (1966):5-80, with a 1417 inventory from Mantua beginning on p. 24; Luciana Gargan, Lo studio teologico e la biblioteca dei domenicani a Padova nel tre e quattrocento (Padua: Antenore, 1971), with a 1390 inventory, pp. 191-220. 
reader can begin to share Thomas's passion for rigorous readings, in which single words and phrases very much matter, she will hardly make progress in reading what theology he writes.

It is all the more awkward, then, to realize that there are some very important authorities to which we hardly have access. Obvious examples are the Glossa ordinaria on Scripture and the Dominican liturgy. It is famously true that there is no edition of the Glossa such as Thomas would have found it, and yet dozens of arguments in some of his most important texts turn on citations to the Glossa. ${ }^{7}$ The lack of a Dominican liturgy may seem less painful at first glance, since there are relatively few arguments in Thomas from liturgical texts. ${ }^{8}$ Those arguments are not the reason for wanting to know more of Dominican liturgy. I suspect that many of Thomas's citations to Scripture are as properly conditioned by their liturgical as by their scriptural contexts. For the moment, this must remain a suspicion. There are few helps for discovering how a text would have been heard by Thomas in his community's public prayer. For the period before about 1256, one would have to go from house to house, manuscript to manuscript, according to Thomas's (presumed) biography. For the standardized Dominican liturgy after 1256, there are several exemplary copies, including one made at St.-Jacques during Thomas's first regency there. ${ }^{9}$ These exemplars remain almost entirely in manuscript.

Next to be hunted are implicit or unnamed sources. There are the notorious quidam-references, the allusions to anonymous authors

7. The Biblia latina cum glossa ordinaria . . . et interlineari ... printed by Adolf Rusch in Strasbourg about 1480 does reflect the text and arrangement of some twelfthcentury copies of the gloss. It has recently been reprinted in facsimile under the direction of Karlfried Froehlich and Margaret T. Gibson (Turnhout: Brepols, 1992). But the Strasbourg version is not always what Thomas reads in his Glossa.

8. For example, Summa theol. 1.31 .4 ob $4,1.52 .1 \mathrm{sc}, 1-2.113 .9 \mathrm{sc}, 2-2.82 .3$ ad 2, 2-2.82.4 sc, 2-2.83.17 co, 2-2.124.2 co, 2-2.154.5 co, 2-2.176.2 ob 1, and so on.

9. London, British Library, Additional MS 23,935. Part of the lectionary from this manuscript has been edited in Maura O'Carroll, "The Lectionary for the Proper of the Year in the Dominican and Franciscan Rites of the Thirteenth Century," Archivum Fratrum Praedicatorum 49 (1979): 79-103. Humbert's liturgical reforms have also been discussed in comparison with earlier Dominican rites by Ansgarius Dirks, especially in his "De liturgiae dominicanae evolutione," Archivum Fratrum Praedicatorum 52 (1982): 5-76; 53 (1983): 53-145; 54 (1984): 39-82; 55 (1985): 5-47; and 57 (1987): 25-30. But we still do not have an edition even of the whole of Humbert's norms. 
or arguers. Then a reader must try to recognize invisible allusionspassages in which there is nothing to suggest that Thomas is quoting or paraphrasing when he is in fact doing so. It was known, for example, that Thomas depended on Raymund of Peñafort's Summa de penitentia for citations of canon law, but it had not been widely recognized that there are unmarked quotations of Raymund's Summa de casibus in the text of Thomas's secunda secundae. ${ }^{10}$ Then there are the implicit intermediary sources. Many of Thomas's authorities, often the most important, come to him through other authorities, including theological works of reference. For most quotations, Thomas's authority is not the full text of an author he is quoting, but only the quotation itself, taken at second hand from an earlier theologian.

Let me give a single example. The topic is whether and in what way it is true to say that all human wills have one last end. The problem appears prominently in the crucial first Question of the Summa's prima secundae, where it serves to cap the doctrine of the teleology of human volition. ${ }^{11}$ The explicit authority is Augustine, De Trinitate 13.3. Yet Augustine's doctrine there is not exactly on point. Augustine seems to hold, not for a single external end, but for a shared will psychologically discoverable in each human agent. Is Thomas simply misreading Augustine? He is not, but we can learn this only from the parallel Question in Thomas's Scriptum, which puts the issue rather differently: Is there only one end for all right wills? ${ }^{12}$ This formulation of the issue is lifted out of Peter Lombard, ${ }^{13}$ who also cites an Augustinian authority, De Trinitate 11.6. Now the Lombard does misread or misapply Augustine's text. Augustine speaks not of a single end for the wills of different individuals, but of a single end within various acts of the will of a single individual. His misreading not only fixes the formulation of the issue, it gives Thomas confidence

10. The earliest printed remark known to me is that of Leonard Boyle, The Setting of the Summa theologiae of Saint Thomas (Toronto: PIMS, 1982), p. 7. Ignatius Eschmann had also noticed the resemblances and has left some collations of them in his papers.

11. Summa theol. 1-2.1.7.

12. Super Sent. 2.38.1.1, ed. Pierre Mandonnet and M. F. Moos (Paris: Lethielleux, 1929-1947), 2:967.

13. Sententiae in IV libris distinctae 2.38.1.1, ed. Patres CSB (Grottaferrata: Editiones CSB, 1951), 1:548. 
in construing Augustine's mind on the matter. What is decisive in reading the passage at the beginning of the prima secundae of the Summa is not to be led back to De Trinitate 13.3, though that is the "correct" citation, but to be led back to Peter Lombard and his misconstrual of De Trinitate 11.6.

It would be possible to go on with other cases and other kinds of implicit intermediaries, but let me break off to state the more interesting questions raised by these cases and intermediaries. The questions require that a reader relinquish, at last, the troublesome category of "sources." When modern scholars begin to notice the multiplicity of languages in Thomas Aquinas, it is natural that they should want to discover what these languages are and how he used them. We moderns do not yet know even that much. But if we did, we would still not have grasped Thomas's understanding of the multiplicity of theological languages.

\section{THOMAS'S TEACHING ON MULTIPLE LANGUAGES}

In trying to retrace Thomas's conception of the multiplicity of inherited languages, there is at least one longer way and one shorter way. The longer way is to begin from Thomas's teaching on the nature of language, to apprentice oneself to the trivium's arts of language as Thomas receives them, to ascend through the variously self-limiting languages of his arrangement of speculative sciences, and then to grasp, at last, his theological transformations and delimitations of all the previous stages. The shorter way, which is the practicable way, is to take up Thomas's explicit remarks on the multiplicity of languages and then to watch his handling of that multiplicity in the structure of his main works. I begin with the explicit remarks, but not before a warning.

One product of the covert entry of Cartesianism into Scholastic circles was the fantasy of a Thomistic method. It was hoped that a statement of this method could be affixed as saving prologue to the whole corpus. The project immediately met resistance in Thomas's texts. Thomas nowhere speaks for more than a few dozen lines about his procedure. He lets his 'method' be read off from his practice. When 
I say that there are explicit remarks on the multiplicity of languages, I don't mean that the remarks can substitute for an acquaintance with Thomas's handling of particular languages in particular cases. Theological procedure is learned by habituation. The scattered remarks I gather here can serve at best as invitations to appropriate Thomas's teaching practices at proper length.

A first set of explicit remarks on inherited languages lies around the topic of modus loquendi, a text's manner of speaking. 'Modus loquendi' has a specific meaning for Thomas in scriptural exegesis. He inherits a division of scriptural speech into preceptive, exemplary, hortatory, revelatory, and prayerful. ${ }^{14}$ The division is not exhaustive. In his exposition of the Psalms, for example, Thomas explains that prayer speaks in any number of manners according to the "affections and inward changes (motiones) of the one praying." 15 Indeed, the notion of modes of speech is applied, in Scripture and outside it, much more broadly than any single division could suggest. In Scripture, Thomas also discovers allegorical, figurative, and symbolic modi.16 He recognizes that Scripture has many particular rhetorical customs. These must be mastered if one is not to misread.17

Thomas also finds different manners of speech in the national languages. ${ }^{18}$ Within each, there are "common" or "customary" manners of speaking, then technical or special manners (where 'technical'

14. See, e.g., Super Psalmos prol., as in Opera omnia ad fidem optimarum editionum accurate recognita (Parma: P. Fiaccadori, 1852-1873), 14:148a-b, where the list is narrativus, admonitorius et exhortativus et praeceptivus, disputativus, deprecativus vel laudativus. Thomas shortens the list to preceptive, comminatory or promissory, and narrative in Scriptum super Sententiis 1.prol.5 co (Mandonnet and Moos 1:18). Compare Marie-Dominique Chenu, La théologie comme science au 13ème siècle (3d ed., Paris: J. Vrin, 1969), pp. 40-45.

15. Super Psalmos 1 (Opera omnia [Parma] 14:150a).

16. For example, "figurate designet," Quaestiones de quodlibet 3.14.1, edited as Quaestiones quodlibetales by R. Spiazzi, 9th ed. (Turin and Rome, Marietti, 1956), p. 68; "symbolicus," Super Sent. 4.1.1.2.1 ob 3 (Mandonnet and Moos 4:17).

17. For justifications of the indirect speech of Scripture, see also Super Sent. 1.34.3.1, Super Boethii de Trinitate 2.4, Summa theol. 1.1.9.

18. For example, Summa theologiae 1.39.3 ad 2, as in Opera omnia iussu Leonis XIII. P. M. edita (Rome, 1882- ), 4:400, with regard to plural expressions in Greek and Hebrew for God; Sentencia Libri Ethicorum 5.7 (Opera omnia [Leonine] 47:287.40), "per modum loquendi apud Graecos." The point is also made at length in the prologue to the Contra Errores Graecorum pars prior, which will be discussed below. 
translates 'artificialis'). ${ }^{19}$ The most prominent technical modes are found in the bodies-of-knowledge, the scientiae. ${ }^{20}$ The manners of speaking proper to each science are distinguished from the rest in many ways, but chiefly by degree of certainty. Other distinctions of the modus loquendi must be attended to in theology. The circumstances of human embodiment demand extraordinary care in making assertions about the divine. ${ }^{21}$

There is more than one way of speaking in each science, since different authorities speak differently about the same objects. Sometimes the differences are in manner of speaking only. Dionysius the Areopagite will speak in a way that is opposed to the Aristotelian, and yet will speak to the same point. ${ }^{22}$ At other times, a difference in manner of speaking betrays a difference in doctrine. So Aristothe must argue against the Platonic habit of speaking about "Ideas," though he himself will also sometimes speak "in the manner of the Platonists (more Platonicorum)." 23 The modus loquendi in philosophy can become a matter of style-which is not to say, merely a matter of style. Thomas reproves the obscure style of the Platonists and justifies Aristotle in attacking the misunderstandings to which such a style inevitably gives rise. ${ }^{24}$

The complexities of parsing the modus loquendi in a given passage can be illustrated by Thomas's use of the allied notion of condescension (condescensio). The conception is best known in its application to passages of Scripture in which locutions that seem literally false

19. So, for example, the philosophical poems of Empedocles, "quae, quia in Graeco metrice scripta sunt, habent aliquam difficultatem et diversitatem a communi modo loquendi" (Sentencia super Metaphysicam 3.11, edited as In XII. libros Metaphysicorum expositio by M. R. Cathala and R. M. Spiazzi [Turin and Rome: Marietti, 1950], \#478).

20. The modus of each science is both its procedure and the limitations on its speech. See especially Super Boethii de Trinitate expos. cap. 2 and 6.1.

21. Quaestiones disputatae De veritate $23.3 \mathrm{co}$, as in Opera omnia [Leonine] 22:658659; Summa 'contra Gentiles' 4.9.6, ed. Ceslaus Pera, Petrus Marc, and Petrus Caramello (Turin: Marietti and Paris: Lethiellux, 1961-1967), \#3445.

22. Super librum Dionysii De divinis nominibus 4.2., ed. Ceslaus Pera (Turin and Rome: Marietti, 1950).

23. Sent. Eth. 1.6 (Opera omnia [Leonine] 47:22.85); to which compare Sentencia libri Politicorum 1[a].1 (Opera omnia [Leonine] 48:A76.438).

24. Super De div. nominibus prol.; Sentencia Libri De anima 1.8 (Opera omnia [Leonine] 45.1.38.3-22). 
are explained as concessions to the weakness of the first readers. ${ }^{25}$ The applications are not just to Scripture. Thomas finds condescensio in the work of every careful teacher. The teacher does not give a student the whole of an art at once, "but slowly, condescending to his capacity." 26 Thomas mentions condescensio specifically when noting Aristotle's dialectical acceptance of views that he does not hold. ${ }^{27}$ Thomas relies on it implicitly when setting forth the considerations of prudence that limit theological speech in front of those with weak faith or none. ${ }^{28}$

The multiplicity of these manners of speaking is not something that Thomas wants to abolish. He wants instead to enter into many of the languages; to compare them and adjust them one to another; to correct for them where they are misleading or false. Thomas's whole practice as exegete and dialectician is to preserve the multiplicity of inherited languages. His own favored terms and tropes are not replacements for the other languages so much as supplements to them. The distinguishing characteristics of any language must be appreciated exactly by anyone who wants to translate it, and so translation becomes a second point at which Thomas reflects explicitly on inherited languages. His solicitude for translation is famous. Although he did not direct or collaborate with the great Dominican translator, William of Moerbeke, Thomas was eager to acquire Moerbeke's translations as quickly as they appeared. ${ }^{29}$ Thomas himself initiated translations of Greek texts needed in compiling his Gospel gloss, the Catena aurea, about which more in a moment. ${ }^{30}$ Elsewhere, when he had to content himself with extant translations, he collated them assiduously.

Thomas writes about translation most extensively in the Contra errores Graecorum. He means to explain why certain passages in

25. So the primitive cosmology in Genesis, on which see Summa theol. 1.68 .3 co (Opera omnia [Leonine] 5:171), 1.70 .1 ad 3 (5:178). For the condescensio of Scripture generally, see Super De div. nom. 1.2.

26. Summa theol. 2-2.1.7 ad 2 (Opera omnia [Leonine] 8:20).

27. Sentencia Libri De sensu et sensato [1.5] (Opera omnia [Leonine] 45-2.000) = Spiazzi \#66.

28. Consider Super De Trinitate expositio proemii; Contra Gentiles 1.8.

29. See the summary of the negative evidence in Torrell, Initiation, pp. 255-258.

30. Thomas says, "quasdam expositiones doctorum Graecorum in Latinum feci transferri," In Marcum, epist. dedic., as in Catena Aurea, ed. A. Guarienti (Turin and Rome: Marietti, 1953), 1:429. 
ancient authorities strike later readers as doubtful. ${ }^{31}$ Thomas gives as one reason the difference between Greek and Latin as languages. "[M]any things that sound right (bene sonant) in the Greek language often do not sound right in Latin, since the Latins and the Greeks confess the same truth of faith with different words." 32 Thomas's example is the mistranslation of 'hypostasis' by 'substantia'. One can say "rightly and with the catholic faith" that there are in God three hypostases, but not that there are three substantiae. Thomas draws a general consequence: "it belongs to the task of the good translator, in translating what belongs to the catholic faith, to preserve the thought (sententia), while changing the manner of speaking (modus loquendi) according to the particularity (proprietas) of the language into which he translates." 33 If a speaker of Latin cannot properly understand every Latin locution with word-for-word literality, how much less can she translate from another language in such a fashion. 34

Thomas sees clearly that translation is not a mechanical task. It requires, beyond erudition, the many virtues of prudent interpretation. In calling for these virtues, Thomas may seem to commit himself unreflectively to the possibility of translation in every case. While he insists that Greek and Latin will diverge "literally," 35 he does not seem to qualify-or to question-the confidence that some translation is always possible. Thomas appears to have eluded one false optimism about translation only to be trapped by another. This is only an appearance. Thomas's confidence in the possibility of translation is a theological confidence. It extends just to what constitutes the faith. He does hold that translation can preserve the sententia of essential theological teachings - that is, the act of judgment or resolution registered in the words. On Thomas's general account, any mental act

31. Contra errores Graecorum pars prior prol. (Opera omnia [Leonine] 40:A71.1618).

32. Contra errores Graecorum pars prior prol. (Opera omnia [Leonine] 40:A71.4548).

33. Contra errores Graecorum pars prior prol. (Opera omnia [Leonine] 40:A71.6265).

34. Contra errores Graecorum pars prior prol. (Opera omnia [Leonine] 40:A71.6671).

35. At the end of the discussion on the differences between hypostasis and substantia, he adds, "Nec est dubium quin etiam simile sit in aliis multis," Contra errores Graecorum pars prior prol. (Opera omnia [Leonine] 40:A71.60-61). 
is refracted by writing or speaking it. ${ }^{36} \mathrm{~A}$ meditated theological doctrine is refracted even more in its authoritative formulation. Thomas reiterates the dispensability of particular theological utterances with regard to the truths they announce or recall. The letter of the New Testament, for example, is fully subordinate to the law of grace announced through it. Its words are instruments for disposing believers to the inward dictates of the Holy Spirit. ${ }^{37}$ Again, creeds are redacted by the Church as a response to pedagogical needs, but they are always open to qualification and further interpretation in the face of other needs. ${ }^{38}$ Again, authority is given to the words of great theological teachers by the Church in accord with the rule of faith-and only so far as the words serve the upbuilding of faith. ${ }^{39}$

Each of these teachings emphasizes the subservience of words to divine truths. Hence a caution. The truths essential to faith must be articulable in every language. There is no language in which salvation cannot be preached. But there is also no guarantee that a preacher or teacher in one linguistic tradition will recognize appropriate formulations of a saving truth in another linguistic tradition. The capacity for judging translations is an acquired erudition exercised contingently. It is not a form of second sight.

Translation leads to doxography. Translation in the ordinary sense makes doxography possible across linguistic traditions by representing alien views in the prudently chosen equivalents of some common language. Translation in a metaphorical sense is required every time one moves from modus loquendi to modus loquendi within the same national language. Having remarked both these kinds of translation, Thomas considers doxography as well. It would be surprising if he did not, since most of the academic genres within which he writes are doxographical genres.

Doxography is practiced everywhere in Thomas, but the principles of the practice are nowhere stated simply. That is because they are not simple. The doxography of Christian teaching, in particular, provokes

36. I have tried to argue this from Thomas's texts in my Ordering Wisdom (Notre Dame: University of Notre Dame Press, 1986), pp. 31-39. What I give here as statement is there formulated as conclusion (p. 39).

37. Summa theol. 1-2.106.1 co (Opera omnia [Leonine] 7:273b).

38. Summa theol. 2-2.1.10 co \& ad 2 (Opera omnia [Leonine] 8:24).

39. See the striking formulation in Summa theol. 2-2.10.12 co (Opera omnia [Leonine] 8:94a). 
controversial questions about the hierarchy of binding authorities. The hierarchy of authoritative texts in theology not only controls development, it also enacts a reverse chronology. The most authoritative texts within the Church come from the Church's beginnings, and so the history of theology can seem a fall from authenticity. But Thomas is clearly aware of theological development in the ordinary sense. He insists that the faith must be formulated more explicitly in response to new questions or errors. 40 Thomas also knows-how could an author of disputed questions not know? - that interpretation must refer to context, including the circumstances of the author. So, for example, Thomas frequently remarks on Augustine's use of Platonic vocabulary and Platonic argument, and he supplies what he can in order to make that use understandable. ${ }^{41}$

The most sustained remarks on theological doxography come once again in the Contra errores Graecorum. 42 They are Thomas's first reason for our having difficulty with certain passages in ancient authoritative texts. The emergence of new errors with regard to the faith has given occasion for the Church's teachers to formulate contested points "with greater circumspection (maiori circumspectione)."43 Aquinas gives as examples the changes wrought in fighting Arianism and Augustine's increasing care in the face of the Pelagians. So Thomas's immediate predecessors, faced with fresh errors, "speak more cautiously (cautius) and almost more selectively (quasi eliminatius) about the teaching of the faith." 44 If certain locutions in the ancients seem incautious, one ought neither to contemn, nor to reject, nor to rewrite them. One ought rather to "interpret them reverently (exponere reverenter)." 45

40. Summa theol. 2-2.1.9 ad 2 (Opera omnia [Leonine] 8:23), 2-2.1.10 (8:24).

41. See especially Quaestio disputata De spiritualibus creaturis 10 ad 8, as in Quaestiones disputatae II, ed. P. Bazzi et al., 10th ed. (Turin and Rome: Marietti, 1965), pp. 409-410.

42. These are not the only remarks on patristic doxography. For surveys of the whole set, see Walter H. Principe, "Thomas Aquinas' Principles for Interpretation of Patristic Texts," Studies in Medieval Culture 8-9 (1976): 111-121.

43. Contra errores Graecorum pars prior prol. (Opera omnia [Leonine] 40:A71.1923). 40).

44. Contra errores Graecorum pars prior prol. (Opera omnia [Leonine] 40:A71.39-

45. Contra errores Graecorum pars prior prol. (Opera omnia [Leonine] 40:A71.4344). 
We are obliged to take this passage in good faith and not to suspect it immediately as an excuse for exegetical violence in the service of a presumed orthodoxy. What Thomas means by 'exponere reverenter' is not the imposition of a later theological consensus backwards. His point is just the opposite: the earlier writers could not have known the later consensus. Thomas counsels only that the doxographer ought to affirm that earlier Christian writers wrote truly even when their remarks now seem incautious or ambiguous. This counsel assumes a ground of faith outside all possible articulations. A community of faith can be meaningfully asserted behind literally discordant articulations. The doxographer is responsible for making the unity of faith manifest through the history of changing articulations. Since changes will never end so long as history continues, the multiplicity of theological articulations will continue to grow. Moreover, the doxographer's task is not to cancel the earlier formulations, but to save them. Theology ought never to be an abolitio memoriae. It ought be an act of gratitude to one's predecessors acted out as charitable attention to them.

Attention is animated and directed by the needs of the Church's faithful at the time of Thomas's service. The needs cannot be met by piecemeal reinterpretations. They require that the whole of theological truth be spoken anew in the present. They require, in other words, that Thomas take up the reinterpreted authorities into new patterns of theological persuasion.

\section{RHETORICAL STRUCTURES FOR THE MULTIPLICITY OF LANGUAGES}

Thomas's explicit remarks on modus loquendi, on translation, and on doxography are parts of a program that is carried out in the construction of his major works. Indeed, his most famous works explicitly propose reorganizations of inherited languages-where 'languages' is understood to comprise at once manners of speaking, authorities, and national languages. This is what we expect of a thirteenth-century Dominican. The reorganization of sources was a principal preoccupation of mendicant learning. 46 Among Domini-

46. Many of these were the results of teams of researchers. On the importance of these collaborations, see Yves Congar, "In dulcedine societatis quaerere veritatem: Note 
can productions in the decades immediately before Thomas's career as teacher-and leaving aside such genres as the commentaries on Peter Lombard-there are famous instances: the Scriptural postillae, correctoria, and alphabetical concordances produced by the Parisian team under Hugh of St-Cher; ${ }^{47}$ the parts of the Speculum majus of Vincent of Beauvais, in their many redactions; the Summae de vitiis et virtutibus by William Peraldus; ${ }^{48}$ and both the digest of decretals andmore importantly for Thomas-the Summa de casibus by Raymund of Peñafort. 49

To the list of Dominican reference works, there should be added at least one by Thomas, the Glossa continua or Catena aurea. It was among Thomas's most popular writings, to judge from the surviving manuscript evidence, ${ }^{50}$ and it was regularly plundered by Thomas's early readers. ${ }^{51}$ The Catena aurea is a running gloss on the four Gospels, composed of short passages from patristic authors, Latin and

sur le travail en équipe chez S. Albert et chez les Prêcheurs au XIIIe siècle," in $\mathrm{Al}$ bertus Magnus, Doctor Universalis: 1280/1980, ed. G. Meyer and Albert Zimmermann (Mainz: Matthias-Grünewald, 1980), pp. 47-57.

47. On the genesis of this text, see Richard H. and Mary A. Rouse, "The Verbal Concordance to the Scriptures," Archivum Fratrum Praedicatorum 44 (1974): 5-30, at pp. 7-13.

48. For an introduction, see Antoine Dondaine, "Guillaume Peyraut: Vie et oeuvres," Archivum Fratrum Praedicatorum 18 (1948): 162-236.

49. For a survey of Raymund's works, with much emphasis on the manuscript evidence, see Laureano Robles, "Escritores dominicos de la Corona de Aragón (siglos XIII-XV)," in Repertorio de historia de las ciencias eclesiasticas en España, vol. 3 (Salamanca: IHTE, 1971), 11-[177], at pp. 12-53.

50. While we await publication of the index volumes for the complete manuscript listing by Dondaine and Shooner, the best available counts are in James A. Weisheipl, Friar Thomas d'Aquino... (rev. ed., Washington: Catholic University of America Press, 1983). According to Weisheipl's figures, the Catena aurea is the most widely copied of all of Thomas's scriptural works, and except for Thomas's other expository innovation-the literal commentary on Job-it is far and away the most widely copied. So also for the secunda secundae of the Summa, which is not only the most frequently found part of the Summa, but the best attested of any of Thomas's works. Torrell, following Conticello, confirms Weisheipl's numbers for manuscripts of the complete text. See Torrell, Initiation, p. 204.

51. In John of Paris's On Royal and Papal Power (written 1302/1303), for example, Gospel authorities invoked by the papal party are reinterpreted by copying out sections from Thomas's compilation. 
Greek, as well as from the Glossa ordinaria. It is, in fact, something like the Glossa revised to the stricter standards of thirteenth-century patristic erudition. The Catena is justly famous for its ample use of Greek material, but Thomas's contribution is not just the importation of unfamiliar authorities. The whole of the Catena is remarkable for its clarity of organization, its precision of citation, and even its revision of confused or corrupted texts. ${ }^{52}$ The Catena is more than a comprehensive patristic anthology neatly arranged. It is a continuous clarification of patristic passages, that is, a commentary on salient texts of patristic exegesis.

Even so, the Catena aurea is hardly Thomas's most compelling rhetorical invention for uniting and applying authorities. That invention is the secunda secundae of the Summa. The secunda secundae is, even at first glance, a schema for organizing a mass of disordered and contradictory material from previously misconnected discoursefrom casuistry, pastoral or confessional manuals, works of devotion. The achievement of organization is difficult to see unless one has waded through the texts that are Thomas's material. He does not list these texts in the Summa and makes only diffident mention of problems of organization. Thomas does speak the essence of the reorganization when he outlines in the prologue to the secunda secundae the procedure that he will follow. The essential change is to move from a sequential consideration of virtues, gifts, vices, preceptseach traditionally arranged-to a clustered treatment of a virtue, the corresponding gift or gifts, the opposed vices, and the attached affirmative or negative precepts. 53

The shift from sequential to simultaneous or clustered consideration requires two things. First, there must be a rationalized list of virtues, since the virtues now serve as the principle of sequence. Second, there must be means for linking the gifts, vices, precepts, beatitudes, and fruits of the Spirit to each virtue. Thomas justifies the reduction to the three theological and four cardinal virtues in the prologue itself. He argues for the appropriateness of the attachments within each cluster as he goes along. My point here is not to rehearse his arguments, but to notice the extraordinary reorganization that they warrant. The

52. In Matt. epist. dedic. (Guarienti 1:4).

53. Summa theol. 2-2.prol (Opera omnia [Leonine] 8:5). 
new order clarifies and makes possible an overview of what had been a labyrinth of divisions and examples. It does away with unhelpful though traditional ways of viewing moral life, such as the primacy of the seven capital sins.

Still, Thomas's achievement is not merely a lucid cataloguing. Here, as in the Catena aurea, he does more than offer a fair and perspicuous arrangement of theological opinions. The secunda secundae presents an arrangement that comprehends the opinions as it leads through them to the end of theology, namely, the quickened pursuit of God. I have in mind something like the contrast between a taxonomy and a protreptic, between a classification and an exhortation. What Thomas does in the secunda secundae is to invent a simplifying classification for moral teachings that is simultaneously an exhortation to the good described in those teachings.

Here again Thomas relies on a theological principle to guarantee the possibility and the appropriateness of what he undertakes. The principle is that of the unity of theology. As Thomas has explained at the very beginning of the prima pars, theology is unified by its distinctive ratio cognoscibilis, its intelligible perspective: Theology is the science that treats everything as revealed by God in order that human beings might attain their end in God. 54 There are a number of consequences, including a prohibition against breaking theology into autonomous sub-disciplines. There is no moral theology in Thomas; there is only a moral "part" or "consideration" within theology. The unity of theology is secured teleologically. More: Theology exists just because we need to be taught how to attain our end. What is not ordered to our end is not theology. Hence it must be possible and appropriate to organize inherited theological languages into a unified rhetorical structure that points to this end.

The Summa theologiae is a structure for ordering the multiplicity of languages around topics and for ordering topics pedagogically to the illumination and attainment of the human end. This structure supposes at least three things. It supposes, first, that responsible pedagogy cannot take place except by entering into the multiplicity of languages. It holds, second, that the multiple languages can be made to correct and complete one another topic by topic. It affirms,

54. Summa theol. 1.1.1 co. 
third, that the topically arranged multiplicity of languages can lead to a single pedagogical end. If the theological principle of the unity of theology gives warrant for these suppositions, it hardly renders them self-evident. I would like to end by trying to give them some evidence-which is to say, by trying to answer the question, why Thomas thinks that a multiplicity of languages must be preserved in the teaching of theology. How can we explain to ourselves Thomas's ways of inheriting the multiplicity of theological languages? How do we translate his principles for constructing the Summa?

\section{TRANSLATING THOMAS'S UNDERSTANDING OF THE MULTIPLICITY OF LANGUAGES}

Some might begin to address these questions by attempting comparisons with the assumptions or claims in contemporary debates about theological interpretation. I will not. Too much violence is needed, I think, to draw such topical comparisons quickly-and an essay of necessity moves quickly. There is also and obviously no common or neutral language of interpretation shared by contemporary debaters themselves. An all-too-common term like "incommensurability," for example, will not only turn out to rest on a dubious analogy to plane geometry, but also to mean a dozen different things depending on who is using it. Perhaps something will be gained if I can rehearse, in my more or less contemporary English, what I take to be Thomas's reasons for writing theology as a rhetorically ordered multiplicity of inherited languages.

For Thomas, the first step in speaking about the divine is an act of renunciation. The speaker must renounce the familiarity of the mother tongue. We are accustomed to call this demand for renunciation a "doctrine," the "doctrine of the divine names." The tag is superficial. The "doctrine of divine names," as Thomas learns it from Ps-Dionysius and Maimonides among many others, is a critique of linguistic immediacy. What is most familiar to human beings in their languages-daily uses, functions in the economy of human desires, "fit" onto the world-must be denied. The speaker who would speak about God must replace familiarity with strangeness, immediacy with an unimagined irony. 
The denial is not uniform. It operates on different classes of locutions differently. These classes, as Thomas affirms with Ps-Dionysius, can be pedagogically arranged. The theological speaker can be led to perform a sequence of renunciations. Thomas reads in Ps-Dionysius and learns in the practices of the theological schools known to him that ordered linguistic renunciation is fostered and required by apprenticeship to a multiplicity of authoritative languages. Linguistic multiplicity is honored in the form of Scripture-with its multiple authors, modes of speaking, genres, audiences. So far as theology remains for Thomas the teaching of the "sacred page," it enacts the speaking of a series of languages. It leads those who hear it or read it to loosen their unreflective grip on one language. So far as Scripture depicts the ways in which languages shatter against the divine, it leads its appropriate readers to a less untrue activity of speaking about God.

I say "activity of speaking," because I believe that the linguistic renunciation is not inscribed in words or single locutions. It is not some typographical convention for using a word "under erasure." Some accounts of theological language treat it as a heap of cold, leaden lumps that must be warmed and reworked before they can have effect. A rhetorically minded reader insists that theological language is hardly inert. It has its own purposes, projects its own pedagogies, constitutes its own posterities. To enter a pedagogy is to lend one's lived time to the retelling of the text's narrative-which is to say, the reenactment of its teaching. The rhetorically minded reader sees that to read theology well is to be invited in as protagonist in a curriculum that is a narrative, in a school of comprehensive persuasion.

For a Christian, the privileged curriculum is traced out by the sequence of languages in Scripture. If there is to be anything spoken or written besides Scripture, and Scripture itself demands that there must be, then theological speakers will have to make rhetorical forms that incorporate Scripture or mimic it, while leading to the end that is also Scripture's end. Thomas sees Ps-Dionysius as a theologian who builds a curricular narrative out of the multiple locutions of the Scriptures. The curriculum ends by pointing to mystical union. Further on in the swelling sound of texts, Thomas composes a curriculum out of Scripture and the generations of speaking descended from it. This is Thomas's enactment of the Dionysian pedagogy. It is his way of practicing apophatic theology while writing a Summa of a million and a half words. 
Thomas does not expect that a single language can be imposed universally on all. He does not try. He takes a multiplicity of theological languages as inevitable given human diversity and human history. He takes the multiplicity as desirable given the weakness of human understanding and the consequent poverty of speech. Thomas does think it possible for the reader to move among languages with understanding and to be moved through them to a single end. In this way, hierarchies of inherited theological languages begin to imitate the plenitude of scriptural rhetoric, though they never equal it.

The criterion for judging the success of Thomas's constructions is not the criterion of propositional picturing. It is the criterion of healthy persuasion. The end of the Summa is ordered to the end of human living, the return of human beings to God through Christ. So far as the Summa is successful in orchestrating the multiplicity of theological languages, it succeeds in persuading a reader to step back from the idolatry of some familiar language, the mother tongue. To step back is to free oneself for a curriculum of persuasions, a narrative of sequential convictions. This curriculum, which mediates the rule of faith to a particular pedagogical need, is Thomistic theology's best means of preparing its students for union with God. 